\title{
Actinomyces dentalis sp. nov., from a human dental abscess
}

\author{
Val Hall, ${ }^{1}$ Matthew D. Collins, ${ }^{2}$ Paul A. Lawson, ${ }^{2}$ Enevold Falsen ${ }^{3}$ \\ and Brian I. Duerden ${ }^{1}$ \\ ${ }^{1}$ Anaerobe Reference Laboratory, NPHS Microbiology Cardiff, University Hospital of Wales, \\ Cardiff CF14 4XW, UK \\ ${ }^{2}$ School of Food Biosciences, University of Reading, Reading, UK \\ ${ }^{3}$ Culture Collection, Department of Clinical Bacteriology, University of Göteborg, Göteborg, \\ Sweden
}

\begin{abstract}
A previously undescribed filamentous, beaded, Gram-positive, rod-shaped bacterium was isolated from pus of a human dental abscess. Based on its cellular morphology and the results of biochemical testing the organism was tentatively identified as a member of the genus Actinomyces, but it did not correspond to any currently recognized species of this genus. Comparative 16S rRNA gene sequencing studies showed the bacterium represents a distinct subline within the genus Actinomyces, clustering within a group of species that includes Actinomyces bovis, the type species of the genus. Sequence divergence values of $>8 \%$ with other recognized species within this phylogenetic group clearly demonstrated that the organism represents a hitherto unknown species. Based on biochemical and molecular phylogenetic evidence, it is proposed that the unidentified organism recovered from a dental abscess be classified as a novel species, Actinomyces dentalis sp. nov. The type strain is R18165 $\left(=\right.$ CCUG $48064^{\top}=$ CIP $\left.108337^{\top}\right)$.
\end{abstract}

The genus Actinomyces embraces a phenotypically diverse range of facultatively anaerobic to aerotolerant, non-sporeforming, Gram-positive, non-acid-fast, rod-shaped organisms that reside taxonomically in the Actinomycineae within the Actinobacteria. Actinomyces species primarily occur as part of the facultatively anaerobic indigenous microflora of human and animal mucous membranes (e.g. oral cavity, intestinal tract and female genital tract). The genus Actinomyces houses several long-established human pathogens. Some species cause the inflammatory disease actinomycosis, whereas others are associated with various nonspecific inflammatory processes, or may play a role in the development of dental plaque and subsequent caries or periodontal diseases (Schaal, 1998). In recent years the classification and identification of Actinomyces species has greatly improved (Funke et al., 1997a) and there has been a dramatic expansion in the number of recognized species (e.g. Collins et al., 2000; Funke et al., 1994, 1997b; Hall et al., 2002; Lawson et al., 2001; Nikolaitchouk et al., 2000; Pascual et al., 1997; Wüst et al., 1995). Most of these newly defined species have originated from human sources, and the Actinomyces flora of humans is now much better established. However, despite this increase in the number of recognized species, there is evidence from genetic profiling

The GenBank/EMBL/DDBJ accession number for the 16S rRNA gene sequence of strain CCUG $48064^{\top}$ is AJ697609. (amplified 16S rRNA gene sequence restriction analyses) studies of Actinomyces-like organisms recovered from human clinical materials that much diversity remains to be characterized (Hall et al., 2001). In the course of an on-going study to elucidate the taxonomic diversity of the Actinomyces flora of humans, we have characterized an organism that, although phenotypically consistent with the genus Actinomyces, does not appear to correspond to any recognized species. Based on the presented findings, we describe another novel species of the genus Actinomyces, Actinomyces dentalis sp. nov.

The bacterial isolate designated $\mathrm{R} 18165^{\mathrm{T}}$ was isolated in Edinburgh in 2003 from pus of a dental abscess from a 72-year-old female patient with facial swelling. The isolate was referred to the Anaerobe Reference Laboratory, NHPS Microbiology Cardiff, University Hospital of Wales, Cardiff, for identification. No further clinical information is known. For biochemical testing the strain was cultured on Columbia agar (Difco) supplemented with $5 \%$ horse blood at $37^{\circ} \mathrm{C}$ and was incubated anaerobically. The strain was biochemically characterized using both conventional tests by the agar plate method of Phillips (1976) and the commercially available API rapid ID32Strep, API rapid ID32A and API Coryne systems according to the manufacturer's instructions (API bioMérieux). Volatile and non-volatile end products of glucose metabolism were detected by GLC 
(Holdeman et al., 1977). The G + C content of the DNA was determined by HPLC according to the method of Mesbah et al. (1989) except that the methanol content of the chromatographic buffer was decreased to $8 \%$ and the temperature was increased to $37^{\circ} \mathrm{C}$. Amplified 16S rRNA gene sequence restriction analyses were performed using HaeIII and HpaII as described by Hall et al. (1999). The 16S rRNA gene of the isolate was amplified by PCR and sequenced directly using a Taq Dye-Deoxy terminator cycle sequencing kit (Applied Biosystems) and an automatic DNA sequencer (model 373A; Applied Biosystems). The closest known relatives of the new isolate were determined by performing GenBank/EMBL database searches. These sequences and those of other known related strains were retrieved from GenBank and aligned with the newly determined sequence using the program SEQTOOLS (Rasmussen, 2002). The resulting multiple sequence alignment was corrected manually using the program GENEDOC (Nicholas et al., 1997) and a phylogenetic tree was constructed according to the neighbour-joining method with the programs SEQTOOLS and TREEVIEW (Page, 1996); the stability of the groupings was estimated by bootstrap analysis (1000 replications) using the same programs.

The unidentified organism recovered from dental abscess pus consisted of filamentous, beaded, branching, Grampositive, rod-shaped cells. Cells were non-acid-fast, nonspore-forming and non-motile. After $48 \mathrm{~h}$ of anaerobic incubation on fastidious anaerobe agar with $5 \%$ horse blood, colonies were tiny, white and breadcrumb-like and pitted the agar. The organism was catalase-negative and grew under anaerobic conditions; it did not grow in air or in air plus $\mathrm{CO}_{2}(5 \%)$. The end products of glucose metabolism were lactic acid (major) and acetic acid (minor); succinic acid was not detected. Using conventional biochemical testing, the organism produced acid from cellobiose, fructose, glucose, lactose (weak), mannose, melibiose, raffinose, sucrose and trehalose but not from arabinose, mannitol or xylose. The organism failed to hydrolyse gelatin or starch. It was urease-negative, did not produce indole and failed to reduce nitrate. Employing commercial API biochemical kits, the strain was unidentified. Using the API Rapid 32Strep system, the organism formed acid from maltose, melibiose, raffinose, sucrose and trehalose but failed to produce acid from D-arabitol, L-arabinose, cyclodextrin, glycogen, lactose, mannitol, melezitose, methyl $\beta$-D-glucopyranoside, pullulan, ribose, sorbitol or tagatose. Activity was detected for $\alpha$-galactosidase and $\beta$-glucosidase; activity for $\beta$-galactosidase was either weakly positive or negative. All other enzyme tests in the Rapid 32Strep system were negative. The organism failed to hydrolyse hippurate and did not produce acetoin. Using the API Coryne system, acid was formed from glucose, maltose and sucrose but not from glycogen, lactose, mannitol, D-ribose or D-xylose. The organism hydrolysed aesculin but not gelatin, and it failed to reduce nitrate. It displayed activity for $\alpha$-glucosidase and $\beta$-galactosidase, but all other enzyme tests in this kit were negative. With the API Rapid ID 32A system, the organism produced acid from mannose and raffinose and gave positive reactions for alanine arylamidase, arginine arylamidase, $\alpha$-galactosidase, $\beta$-galactosidase, $\alpha$-glucosidase, $\beta$-glucosidase, glycine arylamidase, proline arylamidase, leucine arylamidase, phenylalanine arylamidase and histidine arylamidase (weak). All other tests were negative with this test system.

The cellular morphology and general physiological and biochemical reactions of the organism were consistent with its tentative assignment to the genus Actinomyces, but it did not appear to correspond to any recognized species of this genus. To investigate the possible association of the unknown bacterium with other Actinomyces species, amplified 16S rRNA gene sequence restriction analysis was performed. The unknown organism produced a unique $16 \mathrm{~S}$ rRNA gene sequence restriction pattern with HaeIII and HpaII (profile 107/099) and was distinct from the profiles derived from analysis of over 800 Actinomyces strains (Hall et al., 2001). To investigate the phylogenetic relationships of the unidentified organism, its almost complete $16 \mathrm{~S}$ rRNA gene sequence ( $>1400 \mathrm{nt}$ ) was determined. Sequence database searches confirmed that the unknown isolate was most closely related to species of the genus Actinomyces. Treeing analysis demonstrated that the unidentified bacterium was most closely associated with a distinct cluster of species within the genus Actinomyces that includes Actinomyces bovis, the type species (Fig. 1). The nearest sequence to the unknown isolate corresponded to an uncultured rDNA clone from the oral cavity (GenBank accession no. AY278610) whereas the nearest recognized species corresponded to Actinomyces gerencseriae and Actinomyces israelii (Fig. 1).

From both phenotypic and molecular phylogenetic evidence, it is clear that the unidentified, strictly anaerobic, Gram-positive, filamentous, rod-shaped bacterium from a dental abscess represents a novel Actinomyces species. Phylogenetically the unknown bacterium forms a distinct subline within the genus Actinomyces and displays an affinity with a cluster of species that can be regarded as Actinomyces sensu stricto, and that includes A. bovis, Actinomyces catuli, Actinomyces naeslundii, Actinomyces bowdenii, Actinomyces viscosus, A. israelii, A. gerencseriae, Actinomyces oricola, Actinomyces howellii, Actinomyces denticolens, Actinomyces radicidentis, Actinomyces slackii and Actinomyces urogenitalis. Sequence searches of GenBank revealed the closest sequence to the novel organism corresponded to an rDNA clone derived from a human oral cavity. Although the association between the unknown organism and the oral rDNA clone was statistically significant, a sequence divergence value of $4 \%$ indicated the clone was derived from a closely related, albeit different, species from that of the unidentified isolate. Treeing analysis indicated that the nearest recognized species to the unknown organism corresponded to A. israelii and A. gerencseriae, although sequence divergence values of approximately 8 and $10 \%$, respectively, with the 


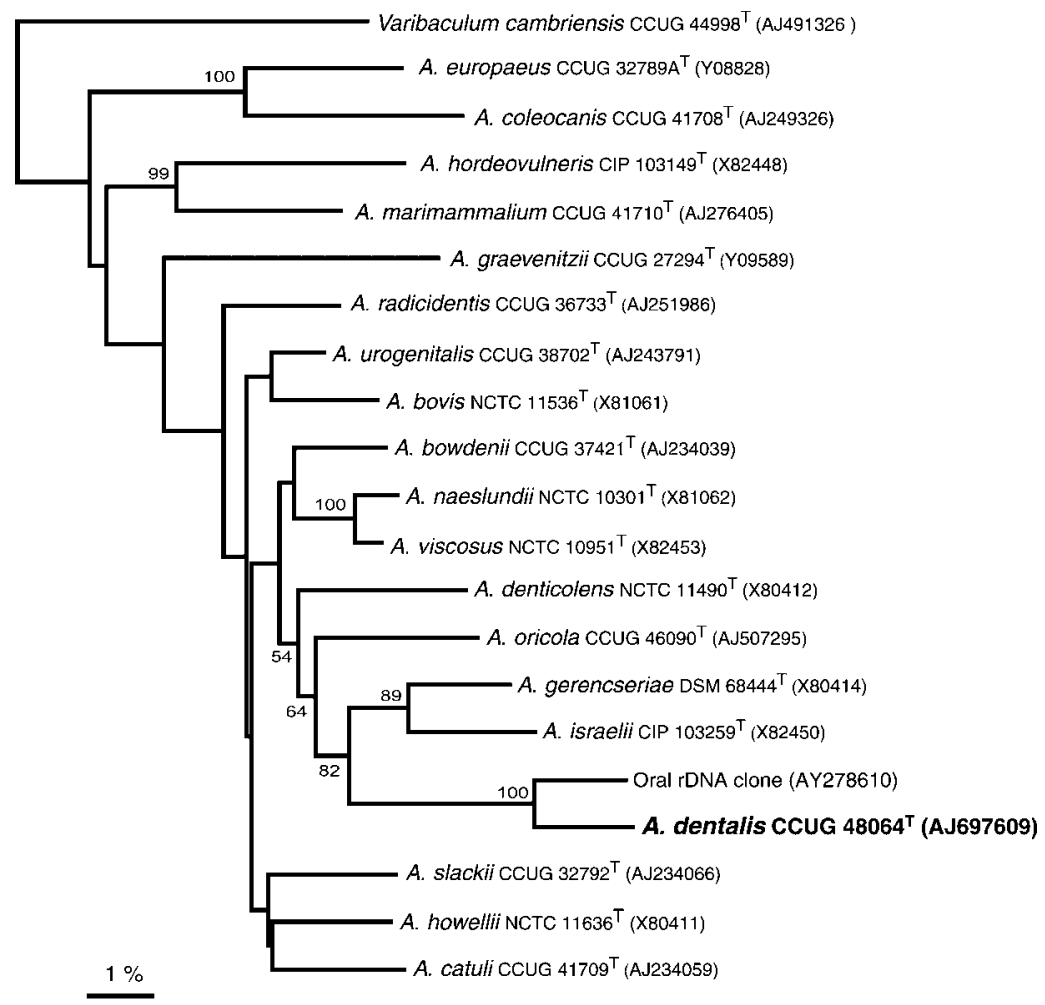

Fig. 1. Unrooted tree based on $16 \mathrm{~S}$ rRNA gene sequences showing the phylogenetic relationships of Actinomyces dentalis sp. nov and some other closely related species of the genus Actinomyces. The tree, constructed using the neighbour-joining method, was based on a comparison of about 1327 nt. Bootstrap values, expressed as percentages of 500 replications, are given at branching points. Bar, 1 substitution per 100 nt.

unknown organism showed that this relationship was not particularly close. Although it is not possible to delineate species solely on the basis of percentage 16S rRNA gene sequence divergence, it is now generally accepted that organisms displaying values of $3 \%$ or more do not belong to the same species (Stackebrandt \& Goebel, 1994). The observed $8 \%$ or more sequence divergence between the unidentified clinical isolate and all currently defined Actinomyces species is therefore consistent with separate species status. Strong support for the separateness of the unknown bacterium also comes from phenotypic evidence. Biochemically the unidentified bacterium can be distinguished from all currently described Actinomyces species. The novel organism can be readily identified using either conventional biochemical criteria or by miniaturized commercial test systems. In particular, the production of API Coryne numerical profile 0450121 serves to distinguish the unknown oral bacterium from all recognized Actinomyces species. Therefore, based on the distinct phenotypic characteristics of the unidentified rod-shaped bacterium and molecular phylogenetic evidence, we consider it warrants classification as a novel species of the genus Actinomyces, for which the name Actinomyces dentalis sp. nov. is proposed. Although only a single strain of $A$. dentalis is currently known, we consider that the formal description of this species together with biochemical criteria to aid its identification will in the future facilitate its routine recognition in the laboratory, thereby permitting the recovery of additional strains and an evaluation of its distribution, clinical prevalence and possible significance. Tests that are useful in distinguishing A. dentalis from its closest relatives are shown in Tables 1 and 2. Phylogenetically A. dentalis forms a distinct subline within an rRNA subcluster that can be regarded as the genus Actinomyces sensu stricto. It is pertinent to note, however, that current knowledge of the phylogenetic structure of the genus Actinomyces and related taxa is based solely on 16S rRNA gene sequences. Data

Table 1. Tests useful in distinguishing Actinomyces dentalis sp. nov. from closely related Actinomyces species using the API Coryne test system

Taxa: 1, A. dentalis sp. nov.; 2, A. bowdenii; 3, A. denticolens; 4, A. gerencseriae; 5, A. urogenitalis; 6, A. naeslundii; 7, A. slackii; 8, A. viscosus; 9, A. israelii; 10 , A. oricola.,$+>90 \%$ give positive reactions;,$-<10 \%$ give positive reactions; $\mathrm{v}$, variable.

\begin{tabular}{|c|c|c|c|c|c|c|c|c|c|c|}
\hline Characteristic & 1 & 2 & 3 & 4 & 5 & 6 & 7 & 8 & 9 & 10 \\
\hline \multicolumn{11}{|l|}{ Acid from: } \\
\hline Lactose & - & + & + & + & + & $\mathrm{V}$ & + & $\mathrm{V}$ & + & - \\
\hline Mannitol & - & - & $\mathrm{V}$ & - & V & - & - & - & $\mathrm{V}$ & - \\
\hline Ribose & - & $\mathrm{V}$ & + & + & $\mathrm{V}$ & $\mathrm{V}$ & - & + & + & - \\
\hline Xylose & - & - & $\mathrm{V}$ & + & + & - & + & - & + & - \\
\hline \multicolumn{11}{|l|}{ Activity for:* } \\
\hline PYRZ & - & $\mathrm{V}$ & $\mathrm{V}$ & + & - & + & + & + & $\mathrm{v}$ & + \\
\hline PAL & - & $\mathrm{V}$ & + & - & $\mathrm{V}$ & $\mathrm{V}$ & - & + & - & + \\
\hline$\beta$-NAG & - & - & - & - & + & - & - & - & - & - \\
\hline Nitrate reduction & - & + & + & - & + & + & + & + & $\mathrm{V}$ & - \\
\hline
\end{tabular}

*PYRZ, Pyrazinamidase; PAL, alkaline phosphatase; $\beta$-NAG, $N$ acetyl- $\beta$-glucosaminidase. 
Table 2. Tests useful in distinguishing Actinomyces dentalis sp. nov. from closely related Actinomyces species using conventional phenotypic methods

Taxa: 1, A. dentalis sp. nov.; 2, A. bowdenii; 3, A. denticolens; 4, A. gerencseriae; 5, A. urogenitalis; 6, A. naeslundii; 7, A. slackii; 8, A. viscosus; 9, A. israelii; 10 , A. oricola.,$+>90 \%$ give positive reactions;,$-<10 \%$ give positive reactions; $V$, variable; ND, not determined.

\begin{tabular}{|lcccccccccc|}
\hline Characteristic & $\mathbf{1}$ & $\mathbf{2}$ & $\mathbf{3}$ & $\mathbf{4}$ & $\mathbf{5}$ & $\mathbf{6}$ & $\mathbf{7}$ & $\mathbf{8}$ & $\mathbf{9}$ & $\mathbf{1 0}$ \\
\hline Acid from: & & & & & & & & & & \\
$\quad$ Arabinose & - & - & - & - & $\mathrm{V}$ & - & - & - & + & - \\
Cellobiose & + & $\mathrm{ND}$ & $\mathrm{V}$ & + & $\mathrm{ND}$ & $\mathrm{V}$ & - & - & + & + \\
Mannitol & - & - & + & + & $\mathrm{V}$ & - & - & - & $\mathrm{V}$ & $\mathrm{V}$ \\
$\quad$ Xylose & - & - & - & + & + & - & - & - & + & $\mathrm{V}$ \\
Catalase production & - & + & - & - & - & $\mathrm{V}$ & + & + & - & - \\
Nitrate reduction & - & + & + & $\mathrm{V}$ & + & + & $\mathrm{ND}$ & $\mathrm{V}$ & $\mathrm{V}$ & + \\
& & & & & & & & & & \\
\hline
\end{tabular}

derived from other independent molecular chronometers are necessary to confirm these phylogenetic inferences.

\section{Description of Actinomyces dentalis sp. nov.}

Actinomyces dentalis (den.ta'lis. N.L. masc. adj. dentalis pertaining to teeth).

Gram-positive, filamentous, beaded, rod-shaped cells. Cells are non-acid-fast, non-spore-forming and non-motile. After $48 \mathrm{~h}$ of anaerobic incubation on Fastidious Anaerobe Agar with 5\% horse blood, colonies are tiny, white and breadcrumb-like and pit the agar. Catalase-negative and anaerobic; does not grow in air or in air plus $5 \% \mathrm{CO}_{2}$. The end products of glucose metabolism are acetic and lactic acids. Using conventional tests, acid is formed from cellobiose, fructose, glucose, lactose (weak), mannose, melibiose, raffinose, sucrose and trehalose but not from arabinose, mannitol or xylose. Gelatin, urea and starch are not hydrolysed. Nitrate is not reduced. Using commercial API systems, acid is produced from glucose, maltose, mannose, melibiose, raffinose, sucrose and trehalose but not from D-arabitol, L-arabinose, cyclodextrin, glycogen, lactose, mannitol, melezitose, methyl $\beta$-D-glucopyranoside, pullulan, ribose, sorbitol, tagatose or D-xylose. Aesculin is hydrolysed but hippurate is not. Indole is not produced. Activity is detected for alanine arylamidase, arginine arylamidase, $\alpha$-galactosidase, $\alpha$-glucosidase, $\beta$-glucosidase, glycine arylamidase, proline arylamidase, leucine arylamidase, phenylalanine arylamidase and histidine arylamidase (weak); activity for $\beta$-galactosidase may or may not be detected. Activity is not observed for alanine phenylalanine proline arylamidase, alkaline phosphatase, $\alpha$-arabinosidase, arginine dihydrolase, $\alpha$-fucosidase, glycine arylamidase, $\beta$-galactosidase-6-phosphate, glutamic acid decarboxylase, glutamyl glutamic acid arylamidase, $\beta$-glucuronidase, glycyl tryptophan arylamidase, $\beta$-mannosidase, pyroglutamic acid arylamidase, pyrazinamidase, leucyl glycine arylamidase,
$N$-acetyl- $\beta$-glucosaminidase, tyrosine arylamidase, serine arylamidase or urease. Voges-Proskauer negative. Isolated from human dental abscess. Habitat is not known. The DNA G $+\mathrm{C}$ content of the type strain is $62 \mathrm{~mol} \%$.

The type strain is $\mathrm{R} 18165^{\mathrm{T}} \quad\left(=\mathrm{CCUG} \quad 48064^{\mathrm{T}}=\mathrm{CIP}\right.$ $\left.108337^{\mathrm{T}}\right)$.

\section{Acknowledgements}

We are grateful to Hans Trüper for advice on the species name.

\section{References}

Collins, M. D., Hoyles, L., Kalfas, S., Sundquist, G., Monsen, T., Nikolaitchouk, N. \& Falsen, E. (2000). Characterisation of Actinomyces isolates from infected root canals of teeth: description of Actinomyces radicidentis sp. nov. J Clin Microbiol 38, 3399-3403.

Funke, G., Stubbs, S., von Graevenitz, A. \& Collins, M. D. (1994). Assignment of human-derived CDC group 1 coryneform bacteria and CDC group 1-like coryneform bacteria to the genus Actinomyces as Actinomyces neuii subsp. neuii sp. nov., subsp. nov., and Actinomyces neuii subsp. anitratus subsp. nov. Int J Syst Bacteriol 44, 167-171.

Funke, G., Von Graevenitz, A., Clarridge, J. E., III \& Bernard, K. A. (1997a). Clinical microbiology of coryneform bacteria. Clin Microbiol Rev 10, 125-159.

Funke, G., Alvarez, N., Pascual, C., Falsen, E., Akervall, E., Sabbe, L., Schouls, L., Weiss, N. \& Collins, M. D. (1997b). Actinomyces europaeus sp. nov., isolated from human clinical specimens. Int J Syst Bacteriol 47, 687-692.

Hall, V., O'Neill, G. L., Magee, J. T. \& Duerden, B. I. (1999). Development of amplified 16S ribosomal DNA restriction analysis for identification of Actinomyces species and comparison with pyrolysis-mass spectrometry and conventional biochemical tests. J Clin Microbiol 37, 2255-2261.

Hall, V., Talbot, P. R., Stubbs, S. L. \& Duerden, B. I. (2001). Identification of clinical isolates of Actinomyces species by amplified 16 S ribosomal DNA restriction analysis (ARDRA). J Clin Microbiol 39, 3555-3562.

Hall, V., Collins, M. D., Hutson, R., Falsen, E. \& Duerden, B. I. (2002). Actinomyces cardiffensis sp. nov. from human clinical sources. J Clin Microbiol 40, 3427-3431.

Holdeman, L. V., Cato, E. P. \& Moore, W. E. C. (1977). Anaerobe Laboratory Manual, 4th edn. Blacksburg, VA: Virginia Polytechnic Institute and State University.

Lawson, P. A., Nikolaitchouk, N., Falsen, E., Westling, K. \& Collins, M. D. (2001). Actinomyces funkei sp. nov., isolated from human clinical specimens. Int J Syst Evol Microbiol 51, 853-855.

Mesbah, M., Premachandran, U. \& Whitman, W. B. (1989). Precise measurement of the $\mathrm{G}+\mathrm{C}$ content of deoxyribonucleic acid by high-performance liquid chromatography. Int J Syst Bacteriol 39, 159-167.

Nicholas, K. B., Nicholas, H. B., Jr \& Deerfield, D. W., II (1997). GENEDOC: analysis and visualisation of genetic variation. EMBNEW News 4, 14.

Nikolaitchouk, N., Hoyles, L., Falsen, E., Grainger, J. M. \& Collins, M. D. (2000). Characterisation of Actinomyces isolates from samples from human urogenital tract: description of Actinomyces urogenitalis sp. nov. Int J Syst Evol Microbiol 50, 1649-1654. 
Page, R. D. M. (1996). TREEVIEW: an application to display phylogenetic trees on personal computers. Comput Appl Biosci 12, 357-358.

Pascual, C., Falsen, E., Akervall, E., Sjoden, B. \& Collins, M. D. (1997). Actinomyces graevenitzii sp. nov., isolated from human clinical specimens. Int J Syst Bacteriol 47, 885-888.

Phillips, K. D. (1976). A simple and sensitive technique for determining the fermentation reactions of non-sporing anaerobes. $J$ Appl Bacteriol 41, 325-328.

Rasmussen, S. W. (2002). SEQtools, a software package for analysis of nucleotide and protein sequences. Available at http:// www.seqtools.dk
Schaal, K. P. (1998). Actinomycoses, actinobacillosis and related diseases. In Topley and Wilson's Microbiology and Microbial Infections, 9th edn, vol. 3, pp. 777-798. Edited by W. J. Hausler \& M. Sussman. London: Arnold.

Stackebrandt, E. \& Goebel, B. M. (1994). Taxonomic note: a place for DNA-DNA reassociation and 16S rRNA sequence analysis in the present species definition in bacteriology. Int J Syst Bacteriol 44, 846-849.

Wüst, J., Stubbs, S., Weiss, N., Funke, G. \& Collins, M. D. (1995). Assignment of Actinomyces pyogenes-like (CDC coryneform group E) bacteria to the genus Actinomyces as Actinomyces radingae sp. nov. and Actinomyces turicensis sp. nov. Lett Appl Microbiol 20, 76-81. 